\title{
Perspective \\ Novel Drugs and Therapeutic Targets for Severe Mood Disorders
}

\author{
Sanjay J Mathew*,', Husseini K Manji ${ }^{2}$ and Dennis S Charney' \\ 'Mood and Anxiety Disorders Program, Department of Psychiatry, Mount Sinai School of Medicine, New York, NY, USA; ${ }^{2}$ Laboratory of Molecular \\ Pathophysiology, Mood and Anxiety Disorders Program, National Institute of Mental Heath, Bethesda, MD, USA
}

\begin{abstract}
Monoaminergic-based drugs remain the primary focus of pharmaceutical industry drug discovery efforts for mood disorders, despite serious limitations regarding their ability to achieve remission. The quest for novel therapies for unipolar depression and bipolar disorder has generally centered on two complementary approaches: (I) understanding the presumed therapeutically relevant biochemical targets of currently available medications, and using that knowledge to design new drugs directed at both direct biochemical targets and downstream targets that are regulated by chronic drug administration; and (2) developing pathophysiological models of the illness to design therapeutics to attenuate or prevent those pathological processes. This review describes several promising drugs and drug targets for mood disorders using one or both of these approaches. Agents interacting with non-catecholamine neurotransmitter systems with particular promise for unipolar and bipolar depression include excitatory amino acid neurotransmitter modulators (eg, riluzole, $N$-methylD-aspartate antagonists, and AMPA receptor potentiators) and neuropeptide antagonists (targeting corticotropin releasing factor- $I$ and neurokinin receptors). Potential antidepressant and mood-stabilizing agents targeting common intracellular pathways of known monoaminergic agents and lithium/mood stabilizers are also reviewed, such as neurotrophic factors, extracellular receptor-coupled kinase (ERK) mitogen-activated protein (MAP) kinase and the bcl-2 family of proteins, and inhibitors of phosphodiesterase, glycogen synthase kinase-3, and protein kinase C. A major thrust of drug discovery in mood disorders will continue efforts to identify agents with rapid and sustained onsets of action (such as intravenous administration of ketamine), as well as identify drugs used routinely in non-psychiatric diseases for their antidepressant and mood-stabilizing properties.
\end{abstract}

Neuropsychopharmacology (2008) 33, 2080-2092; doi:I0. I038/sj.npp. I 30 I652; published online 2 January 2008

Keywords: therapeutics; monoamine; glutamate; ketamine; mood stabilizer; mood disorders

\section{WHY INVESTIGATE NEW TARGETS BEYOND MONOAMINES?}

Despite an explosion in psychiatric neuroscience research in the past decade, there is consensus regarding a significant 'pipeline' problem in neuropsychopharmacology (Agid et al, 2007; Pangalos et al, 2007). Given the high lifetime prevalence of DSM-IV mood disorders (20.8\%), with first onset often in childhood or adolescence (Kessler et al, 2005), the public health urgency of identifying safe and more effective treatments for these common and disabling conditions is clear. For unipolar and bipolar disorder, and the commonly comorbid anxiety disorders, there have been very few significant innovations and no genuine breakthrough drugs in the past 2 decades (Spedding et al, 2005).

*Correspondence: Dr S Mathew, Mood and Anxiety Disorders Program, Department of Psychiatry, Mount Sinai School of Medicine, One Gustave L. Levy Place, Box 1217, New York, NY 10029, USA, Tel: + I 21224 | 4480, Fax: + I 21224 | 4542,

E-mail: sanjay.mathew@mssm.edu

Received 27 July 2007; accepted 4 November 2007
Novel therapeutic strategies that accelerate speed of onset, enhance efficacy, and tolerability, while addressing core pathophysiological features of these illnesses are needed.

The limitations of current approaches to drug discovery in neuropsychiatric disorders have been extensively scrutinized (Roth et al, 2004; Wong and Licinio, 2004; Spedding et al, 2005; Berton and Nestler, 2006; Agid et al, 2007). Much of the previous (and current) focus of investigation for mood disorders regards the biology and neural circuitry most relevant to the monoaminergic systems (serotonin (5-HT), norepinephrine (NE), and dopamine (DA)), given the therapeutic benefit of the selective 5-HT reuptake inhibitors (SSRIs), tricyclic antidepressants (TCAs), monoamine oxidase inhibitors (MAOIs), and dopaminergic medications (Mann, 2005; Dunlop and Nemeroff, 2007; Nestler and Carlezon, 2006). A recent modernization of the classical monoamine theory of depression has posited that elevated density of monoamine oxidase A (MAO-A) (the enzyme that metabolizes 5-HT, NE, and DA) is the primary monoamine-lowering process during a major depressive episode, while monoamine transporter density variability plays a secondary role in influencing loss of 
specific monoamines, explaining symptomatic heterogeneity during major depressive episodes (Meyer et al, 2006). Areas of active investigation in monoamine biology include (1) catecholamine depletion studies using acute tryptophan depletion, phenylalanine/tyrosine, or alpha-methyl-paratyrosine (see Ruhe et al, 2007 for review); (2) in vivo brain imaging studies of specific receptors and transporters for these neurotransmitters (eg, Oquendo et al, 2007; Parsey et al, 2006a, b; Bhagwagar et al, 2006; Moses-Kolko et al, 2007); (3) cerebrospinal fluid (CSF) and neuroendocrine challenge studies; (4) postmortem studies; and more recently, (5) large-scale genetic association studies (Hu et al, 2007). Inasmuch as the phenotype of depression is heterogeneous, biological investigations of monoamine systems in diverse patient groups has hindered the ability to reliably uncover abnormalities and has stymied identification of biomarkers. Contradictions in the literature, rather than reflecting minimal involvement of monoaminergic systems in disorder pathophysiology, likely reflect heterogeneity of biological substrates. Phenotypic contributors to mood disorder heterogeneity, which likely impact expression of monoamines (and response to SSRIs and similar drugs), include sex, age of onset (early onset $v s$ mid-life $v s$ late-onset), race/ethnicity, subtype (melancholic $v s$ atypical $v s$ dysthymic), current mood state (euthymic $v s$ depressed), chronicity of illness, previous number of episodes, family history of psychopathology, and axis I-III disorder comorbidity (Trivedi et al, 2006).

Thus, while SSRIs and similar monoaminergic drugs are the mainstays of pharmacological treatment for mood disorders, their limitations in sustaining disorder remission are increasingly apparent. The first phase of the STAR ${ }^{\star} \mathrm{D}$ study, the largest effectiveness study of its kind in 'real world' patients, measured the efficacy of the SSRI citalopram in outpatients with unipolar depression $(n=2876)$. Remission rates were $28 \%$, a remission rate similar to that achieved in standard randomized placebocontrolled acute efficacy trials (Trivedi et al, 2006). As the presence of residual symptoms is a strong predictor of relapse or recurrence (Keller, 2004), optimal therapeutic strategies require a focus on achieving and sustaining remission, by presumably addressing core pathophysiological processes. Non-monoaminergic biological systems have received increasing attention from translational researchers for their potential therapeutic application for mood disorders. The most actively pursued drug targets for unipolar depression include amino-acid neurotransmitter receptors and transporters, neuropeptides (corticotropinreleasing factor (CRF), substance $\mathrm{P}$ ), neurotrophic factors (brain-derived neurotrophic factor (BDNF)), and steroid receptors/hormones (glucocorticoid receptor, DHEA, testosterone, melatonin; see Hasler et al, 2004; Berton and Nestler, 2006; Martinowich et al, 2007 for reviews). It is noteworthy, however, that despite numerous potentially novel targets, relatively few non-monominergicbased drugs will gain FDA approval by the end of this decade, while additional monoaminergic medications, with minimal advantages over existing drugs, will likely gain regulatory approval over the next few years. Table 1 lists medications in phase II and III clinical trials for unipolar major depression (accessed on www.clinicaltrials.gov on 24 July 2007).
Table I Medications in US FDA Clinical Trials for Unipolar Major Depression

\begin{tabular}{|c|c|c|}
\hline Mechanism & Name & Company \\
\hline \multicolumn{3}{|l|}{ Phase III novel mechanism drugs } \\
\hline$\beta 3$-Adrenoreceptor agonist & Amibegron & Sanofi-Aventis \\
\hline GR-II antagonist & Mifepristone & $\begin{array}{l}\text { Corcept } \\
\text { Therapeutics }\end{array}$ \\
\hline $\begin{array}{l}\text { Melatonin MI/M2 agonist, 5-HT2C/2B- } \\
\text { selective }\end{array}$ & Agomelatine & Novartis \\
\hline NK-I antagonist & Casopitant & $\begin{array}{l}\text { GlaxoSmithKline } \\
\text { (GSK) }\end{array}$ \\
\hline NK-I antagonist & L-759274 & Merck \\
\hline NK-2 antagonist & Saredutant & Sanofi-Aventis \\
\hline
\end{tabular}

Phase III monaminergic-based drugs

D2 and 5-HTA antagonist

SNRI

Partial D2 agonist, 5-HTIA partial agonist, 5-HT2A antagonist

5-HT2 antagonist and 5-HT reuptake inhibitor

5-HTIA partial agonist

5-HT reuptake inhibitor and

5-HTIA partial agonist

SNRI

$\begin{array}{ll}\begin{array}{ll}\text { Quetiapine SR } & \text { AstraZeneca } \\ \text { Milnacipran } & \begin{array}{l}\text { Cypress } \\ \text { Bioscience }\end{array} \\ \text { Aripiprazole } & \begin{array}{l}\text { Bristol-Myers } \\ \text { Squibb }\end{array} \\ \text { Trazodone CR } & \text { CSC } \\ \text { Gepirone ER } & \text { Fabre-Kramer, } \\ \text { GSK }\end{array} \\ \begin{array}{ll}\text { Vilazodone } & \text { Genaissance }\end{array} \\ \text { Desvenlafaxine } & \text { Wyeth }\end{array}$

Phase II novel mechanism drugs

CRF-I antagonist

CP 316,311

Pfizer

CRF-I antagonist

GW876008

CRFI antagonist

CP-316, 31।

GSK

CRFI antagonist

BMS-562086

GR antagonist

Mitochondrial benzodiazepine

receptor agonist

NNR antagonist

NK-I antagonist

NK-I antagonist

NK-I antagonist

NMDA (NR2B) glutamate antagonist

Pentapeptide analog of melanocyteinhibiting factor (MIF-I)

Phenylalanine derivative

VIB antagonist

$\begin{array}{ll}\text { Squibb } & \\ \text { Sqistol-Myers }\end{array}$

ORG 34517/ Organon

34850

AC 5216

Dainippon/

Novartis

TRIDMAC Targacept

TAK-637

$$
\text { TAP }
$$

R 673

Vestipitant,

GW597599

Traxoprodil

Nemifitide

Nippon Roche

GSK

Pfizer

YKP IOA

R228060

Tetragenex

SSRI494I5

Janssen, SK

Sanofi-Aventis

Phase II monaminergic-based drugs

Bis-aryl-sulphanyl modulator:

5-HT modulator

DA/NE/5-HT reuptake inhibitor

DA/NE/5-HT reuptake inhibitor

DA/NE/5-HT reuptake inhibitor

DA/NE/5-HT reuptake inhibitor

$\begin{array}{ll}\text { Lu AA21004 } & \text { Lundbeck } \\ \text { DOV 216,303 } & \text { DOV } \\ \text { DOV 21,947 } & \text { DOV/Merck } \\ \text { NS 2359 } & \text { GSK } \\ \text { DOV 21947 } & \text { DOV/Merck }\end{array}$


Table I Continued

\begin{tabular}{lll}
\hline Mechanism & Name & Company \\
\hline DA/NE/5-HT reuptake inhibitor & $\begin{array}{l}\text { GSK372475, } \\
\text { NS2359 }\end{array}$ & $\begin{array}{l}\text { GSK, } \\
\text { NeuroSearch }\end{array}$ \\
Dopamine (D2/D3) agonist & Pramipexole & $\begin{array}{l}\text { Boehringer } \\
\text { Ingelheim }\end{array}$ \\
NERI & NERI IV & $\begin{array}{l}\text { Eli Lilly } \\
\text { Partial D2 agonist }\end{array}$ \\
5-HTIA agonist and 5-HT2 antagonist & Adatanserin & Wyeth \\
5-HTIA agonist, sigma antagonist & PRX-00023 & Epix \\
5-HTIB and 5-HTID antagonist & Elzasonan & Pfizer \\
& hydrochloride & \\
5-HTIA partial agonist & MN-305 & MediciNova \\
Sigma and 5-HTIA agonist & OPC I4523 & Otsuka \\
SNRI & R-sibutramine & Sepracor \\
SRI, 5-HT2 agonist, 5-HTIA and & metabolite & \\
5-HTID agonist & TGBA0IAD & Fabre-Kramer \\
\hline
\end{tabular}

Abbreviations: CRF, corticotropin-releasing factor; DA, dopamine; FDA,

Food and Drug Administration; GR, glucocorticoid receptor; 5-HT, serotonin; $N E$, norepinephrine; NERI, selective norepinephrine reuptake inhibitor; NK, neurokinin; NMDA, N-methyl-D-aspartate; NNR, neuronal nicotinic receptor; VIB, vasopressin IB.

Source: www.clinicaltrials.gov (accessed on 24 July 2007). Table may not be comprehensive of every US FDA registered phase II and III medication trial for unipolar depression. The Table does not include augmentation studies, complementary and alternative medications, or neuromodulation/devices.

In this paper, we highlight several promising areas for therapeutics for mood disorders (unipolar depression and bipolar disorder) based upon two complementary approaches:

(1) Understanding the presumed therapeutically relevant biochemical targets of medications currently in use, and using that knowledge to design new drugs directed at these targets. This includes not only direct biochemical targets, but also downstream targets that are regulated by chronic drug administration (ie, consistent with the clinical temporal profile; Gould et al, 2004a, b).

(2) Understanding the pathophysiology of the illness, and using that knowledge to design therapeutics to attenuate or prevent those pathological processes (Quiroz et al, 2004). As space limitations do not permit an exhaustive discussion of every promising candidate using both strategies, we emphasize compounds with particularly high potential for clinical translation.

\section{AGENTS INTERACTING WITH NON-CATECHOLAMINE NEUROTRANSMITTER SYSTEMS}

\section{Amino-Acid Neurotransmitter Modulators}

Glutamate, the major excitatory neurotransmitter in the brain, is ubiquitous in the mammalian CNS, where it is used in up to $60 \%$ of synapses. The emerging interest in glutamate-modulating agents derives from both a pathophysiological perspective regarding amino-acid neurotransmitters' role in mood disorders as well as evidence that conventional antidepressants have effects on specific glutamate receptor subtypes (Manji et al, 2003; Charney and Manji, 2004). Recent pathophysiological hypotheses proffer a view of dynamic regional amino-acid transmitter dysfunction in severe, recurrent mood disorders, with implications for experimental therapeutics that target-specific ionotropic or metabotropic receptors, glial glutamate transporters, or vesicular glutamate release (Kugaya and Sanacora, 2005; Zarate et al, 2003; Sattler and Rothstein, 2007; see Figure 1, pathways c-f). One prominent model for unipolar depression proposes that disrupted glial cell function in structures relevant to emotional processing such as amygdala, observed in postmortem mood disorder samples (Hamidi et al, 2004), may result in decreased uptake of glutamate, with a resultant elevation of extracellular glutamate levels (Kugaya and Sanacora, 2005). Disruptions in glutamate (Glu)glutamine (Gln) neuronal-glial cycling are believed to cause decreased glutamate release and decreased cortical GABA, examined in vivo in human subjects using techniques such as ${ }^{13} \mathrm{C}$-MRS (Shen, 2006; Mason et al, 2007). A reduction in glial cell function would result in decreased flux through the Glu/Gln and GABA/Gln cycles, findings that are consistent with reduced rates of Glu/Gln cycling and lowered cortical GABA concentrations in individuals with MDD (Kugaya and Sanacora, 2005; Sanacora and Saricicek, 2007). Microarray analysis has demonstrated significant dysregulation of a specific subset of genes encoding the astroglial highaffinity glutamate transporters SLC1A2 (EAAT2; GLT1) and SLC1A3 (EAAT1; GLAST); glutamate-ammonia ligase (glutamine synthetase); and various subunits of glutamate receptors and $\mathrm{GABA}_{\mathrm{A}}$ receptors in anterior cingulate (area 24) and left dorsolateral prefrontal cortex (areas 9 and 46) (Choudary et al, 2005), lending support for regionally specific abnormalities in glutamate function in mood disorders.

The impairment in glial uptake of Glu, and conversion to Gln, would lead to an elevation of extracellular Glu during intense neuronal activity, and serve to activate extracellular $\mathrm{N}$-methyl-D-aspartate (NMDA) receptors associated with various forms of excitotoxicity (Pittenger et al, 2007). Changes in extrasynaptic Glu concentrations can have wideranging effects on diverse physiological functions, including activation of signal transduction pathways involved in the regulation of neurotrophic factors, neuroplasticity, and cellular resilience (Pittenger et al, 2007; see Figure 1). GABAergic involvement in the pathophysiology and treatment of mood disorders is equally compelling, and supported by preclinical studies showing stress-related changes in GABAergic function, GABAergic effects of existing antidepressant medications, antidepressant/ mood-stabilizing efficacy associated with GABAergic drugs, and robust GABAergic abnormalities and genetic associations in depressed patients (see Sanacora and Saricicek, 2007 for recent review).

Antidepressants/mood stabilizers that impact primarily glutamate receptors such as NMDA receptor antagonists, metabotropic glutamate receptor (mGluR) agonists and antagonists, and positive modulators of $\alpha$-amino-3-hydroxy5-methyl-4-isoxazolepropionic acid (AMPA) receptors have 


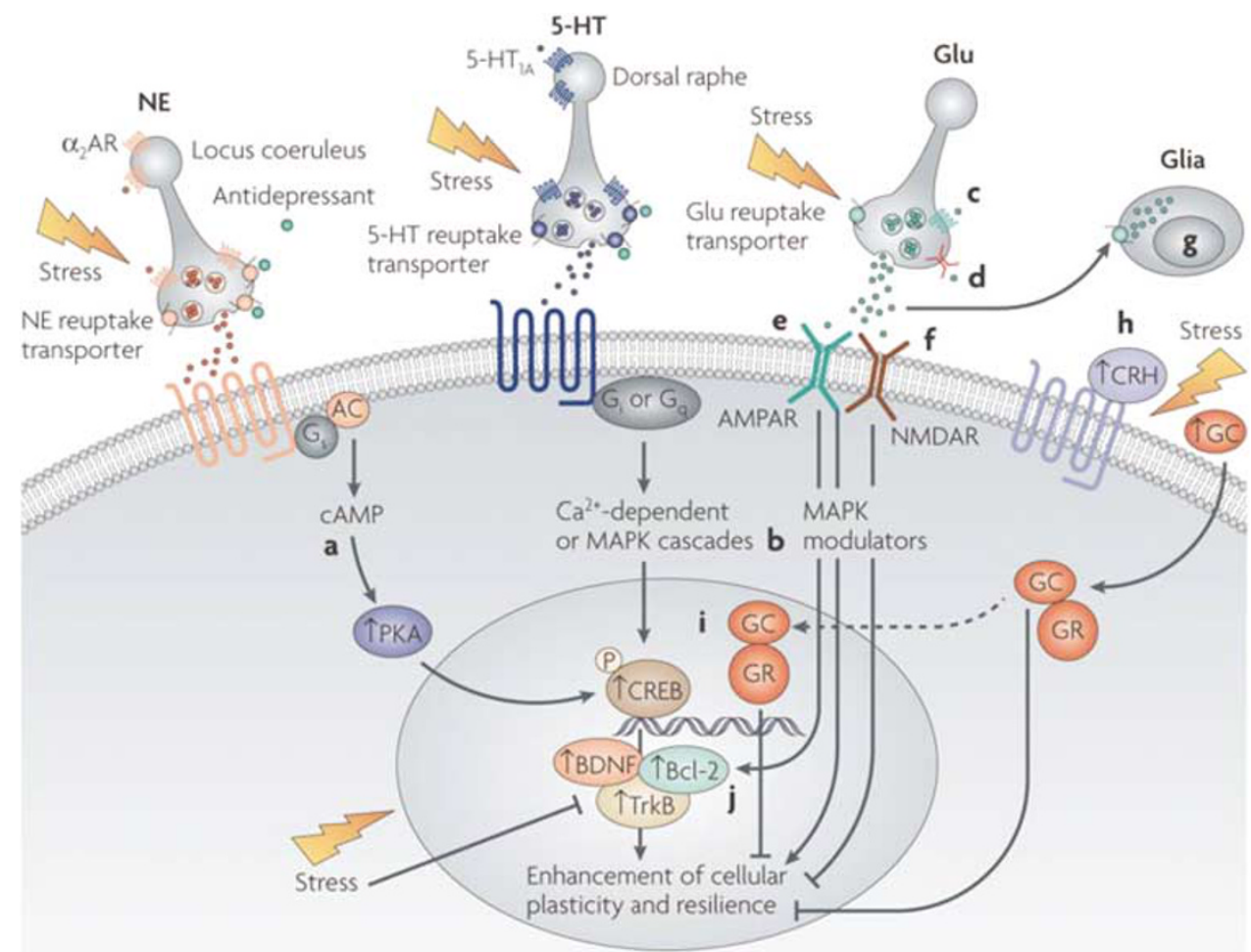

Figure I Plasticity regulators as targets for the development of novel agents for the treatment of mood disorders. This figure depicts the multiple targets by which neuroplasticity and cellular resilience can be increased in mood disorders. (a) Phosphodiesterase inhibitors increase the levels of pCREB; (b) MAP kinase modulators increase the expression of the major neurotrophic protein Bcl-2; (c) mGluR II/III agonists modulate the release of excessive levels of glutamate; (d) drugs such as lamotrigine and riluzole act on $\mathrm{Na}^{+}$channels to attenuate glutamate release; (e) AMPA potentiators upregulate the expression of BDNF; ( $f$ ) NMDA antagonists like ketamine and memantine enhance plasticity and cell survival; (g) novel drugs to enhance glial release of trophic factors and clear excessive glutamate may have utility for the treatment of depressive disorders; (h) CRF antagonists and (i) glucocorticoid antagonists attenuate the deleterious effects of hypercortisolemia, and CRF antagonists may exert other beneficial effects in the treatment of depression via non-HPA mechanisms; (j) agents which upregulate $\mathrm{BCl}-2$ (eg, pramipexole, shown to be effective in bipolar depression; Zarate et al, 2004b). These distinct pathways have convergent effects on cellular processes such as bioenergetics (energy metabolism), neuroplasticity, neurogenesis, resilience, and survival. Nature Reviews Drug Discovery. Modified and reproduced with permission from Charney and Manji (2004).

demonstrated antidepressant-like properties, with potential common downstream mechanisms of action (Paul and Skolnick, 2003; Zarate et al, 2003; Sanacora et al, 2003; Mathew et al, 2005b; see Figure 1). Alterations in neural plasticity in critical limbic and reward circuits, mediated by increasing postsynaptic AMPA to NMDA throughput, may represent a convergent mechanism for therapeutics of severe mood disorders (Schloesser et al, 2008; Figure 1, pathways e, f). In the sections below we discuss several glutamate-modulating approaches that may hold particular promise for unipolar and bipolar depression.

\section{Riluzole (Major Depressive Disorder And Bipolar Depression)}

Riluzole (2-amino-6-trifluoromethoxy benzothiazole) is a neuroprotective agent that is the only FDA-approved medication for amyotrophic lateral sclerosis (ALS), although median survival is only prolonged by about 2-3 months (Miller et al, 2007). Two open-label studies support the potential utility of riluzole in treatment-resistant unipolar depression (Zarate et al, 2004a; Sanacora et al, 2007), and one open-label add-on study found improvements in bipolar depression (Zarate et al, 2005). Interestingly, the patients who responded to riluzole tended to be in remission (ie, almost symptom-free), suggesting that there may be a subgroup of mood disorder patients for whom glutamatergic strategies have considerable utility. Riluzole has complex mechanisms of action; among its actions, it inhibits release of glutamate through inhibition both of voltage-dependent sodium channels and of P/Q-type calcium channels, enhances glutamate reuptake, and upregulates AMPA receptors (reviewed in Zarate et al, 2006b; Mathew et al, 2005b; see Figure 1, pathway d). Riluzole modulates neuroplasticity via stimulation of growth factor synthesis such as BDNF (Mizuta et al, 2001; Katoh-Semba et al, 2002), promotion of neuritogenesis, neurite branching, and neurite outgrowth (Shortland et al, 2006), increasing concentrations of the neuronal marker $\mathrm{N}$-acetyl-aspartate in hippocampus (Mathew et al, in press), and enhancement of surface expression of the hippocampal AMPA receptor subunits (GluR1 and GluR2) (Du et al, 2007). The latter process is implicated in the regulation of activity-dependent synaptic strength and postsynaptic receptor responsiveness (Du et al, 2007).

Riluzole's efficacy has also been reported for patients with generalized anxiety disorder (GAD) (Mathew et al, 2005a; Mathew et al, in press). The relationship between GAD and mood disorders is particularly strong (Moffitt et al, 2007; Kessler et al, 2005), and patients with 'anxious depression' 
likely represent a common and valid subtype of mood disorder (Fava et al, 2004, 2006) and are less likely to achieve remission with standard SSRIs (Trivedi et al, 2006). One intriguing mechanism that could explain riluzole's anxiolytic efficacy is evidence that at higher concentrations, riluzole strongly potentiated postsynaptic $\mathrm{GABA}_{\mathrm{A}}$ receptor function in cultured hippocampal neurons (He et al, 2002). Commonly used anxiolytics such as benzodiazepines bind to and allosterically interact with $\mathrm{GABA}_{\mathrm{A}}$ receptors, which mediate most fast inhibitory neurotransmission. Thus, riluzole may confer antidepressant and anxiolytic activity through numerous mechanisms, and randomized placebocontrolled studies are warranted.

\section{NMDA Receptor Antagonists (Major Depressive Disorder And Bipolar Depression)}

There is substantial evidence that NMDA receptor antagonists have antidepressant properties (Krystal, 2007). Chronic treatment with NMDA antagonists such as MK-801 and AP-7 resulted in antidepressant-like behavioral effects in models such as chronic mild stress, learned helplessness, footshock-induced aggression, and olfactory bulbectomy (reviewed in Paul and Skolnick, 2003). Chronic, but not acute, treatment with NMDA antagonists also resulted in reductions in density of forebrain $\beta$-adrenoreceptors (Paul et al, 1992; Maj et al, 1993) and 5- $\mathrm{HT}_{2}$ receptors (Papp et al, 1994). Similar to monoamine-based antidepressants, NMDA antagonists given to animals processed in the forced swim test resulted in rapid downregulation of forebrain $\beta$-adrenoceptors (Wedzony et al, 1995). Repeated administration of conventional antidepressants has been found to alter the expression of mRNA that encodes NMDA receptor subunits (Boyer et al, 1998), through expression of BDNF (Brandoli et al, 1998).

The above preclinical reports provided a sound rationale for recent exploratory work using NIMDA receptor antagonists in mood disorder patients. Ketamine, a highaffinity non-competitive NMDA antagonist, has been used as a standard anesthetic agent for many years both in pediatrics and in adults, with doses as high as $2 \mathrm{mg} / \mathrm{kg}$ intravenous (i.v.). Two placebo-controlled studies of a single subanesthetic dose of i.v. ketamine $(0.5 \mathrm{mg} / \mathrm{kg}$ infusion over $40 \mathrm{~min}$ ) in unipolar depression (Berman et al, 2000; Zarate et al, 2006a, b), reported rapid although transient antidepressant efficacy. Euphoric and psychotomimetic side effects were observed acutely $(2-4 \mathrm{~h}$ following i.v. administration), but were temporally distinct from the amelioration of core depressive symptoms, which in some cases persisted for up to 1 week. It was shown more recently in rodent models that AMPA receptor throughput is required for the antidepressant-like effect of ketamine, and that ketamine may result in rapid antidepressant effect by enhancing AMPA relative to NMDA throughput in critical neuronal circuits (Du et al, 2006; Maeng et al, 2007; Figure 1, pathway f).

In contrast to the dramatic effects observed in these two i.v. ketamine studies, a placebo-controlled study of the low-to-moderate-affinity non-competitive NMDA antagonist memantine (oral dosing) did not show antidepressant effects (Zarate et al, 2006c). While higher-affinity NMDA antagonists may be required for antidepressant efficacy, i.v. administration may also be an important factor. Important next steps for i.v. ketamine studies in mood disorders include (1) dose-finding studies of i.v. ketamine, as all studies thus far have used fixed $0.5 \mathrm{mg} / \mathrm{kg}$ dosage, in an attempt to balance antidepressant efficacy with side effects; (2) repeated dose administration studies; (3) investigations of whether particular medications may be used in combination with i.v. ketamine to potentiate (and extend) the antidepressant effects; and (4) studies in bipolar depression. Given ketamine's potential for acute psychotomimetic side effects, however, more selective subtype NMDA antagonists, such as NR2B receptor subtype, with lower liability for these side effects, will continue to be explored (Zarate et al, 2007a). Indeed, the NR2B antagonist Ro 25-6981 had antidepressant-like properties in the forced swim test (Maeng et al, 2007). From a safety perspective, this compound also has not been associated with vacuolization in rodents (Gil et al, 2002), in contrast to the reversible vacuolization at high doses observed with noncompetitive NMDA antagonists such as ketamine and dizocilpine (Olney et al, 1989).

\section{AMPA Receptor Potentiators/Ampakines (Major Depressive Disorder)}

AMPA receptors are a subfamily of ionotropic glutamate receptors that mediate the fast component of excitatory neurotransmission, and which, like NMDA receptors, are involved in learning and memory. Several classes of compounds can allosterically modulate AMPA receptors. These compounds (so-called AMPA receptor-positive modulators or AMPA receptor potentiators, ARPs) do not activate AMPA receptors themselves, but slow the rate of receptor desensitization and/or deactivation in the presence of an agonist. Several AMPA receptor potentiators in development have demonstrated antidepressant effects in animal models of depression, including exposure to inescapable stressors, the forced swim test, the tail-suspension-induced immobility test, and learned helplessness models (reviewed in Zarate et al, 2006b). In contrast to traditional antidepressants, this group of compounds does not appear to affect the extracellular concentration of monoamines; however, these drugs can enhance the neurotrophic actions of BDNF mRNA and protein in primary neuronal cultures and in rat brain (Bleakman et al, 2007; Figure 1, pathway e). No placebocontrolled clinical trials in mood disorder patients have been published to date; a phase II trial of an AMPA receptor potentiator for major depression was recently halted due to preclinical toxicity (www.clinicaltrials.gov identifier NCTG00113022).

\section{NEUROPEPTIDES AS THERAPEUTIC TARGETS FOR MAJOR DEPRESSION}

Neuropeptides are short-chain amino acids that act as neurotransmitters in brain circuits implicated in mood and anxiety regulation. Recognition of the large number of neuropeptide targets and the role of stress-related neuropeptides in preclinical models has prompted investigation into the clinical utility of small-molecule neuropeptide 
modulators. Below we review two classes of neuropeptide receptor antagonists that are well represented in phase II and III RCTs of unipolar depression (Table 1): (1) corticotropin-releasing factor-1 (CRF1) receptor, also known as corticotropin-releasing hormone (CRH), antagonists, and (2) neurokinin (NK) receptor antagonists.

\section{Corticotropin-Releasing Factor Antagonists}

Over 20 years of preclinical research have suggested that the 41-amino-acid peptide CRF is an important mediator of the stress response, coordinating the neuroendocrine, autonomic, immune, and behavioral responses to stress, while hyperactivity of the hypothalamic-pituitary-adrenal (HPA) axis has been associated with subgroups of patients with major depression (Holsboer, 2000). Hypothalamic and extrahypothalamic neurons containing CRF1 and CRF2 receptors are located throughout key brain stem, limbic, and cortical regions implicated in affective and anxiety, with CRF1 the predominate subtype in limbic regions and in pituitary regulation of HPA axis activity (Valdez, 2006). Animal models of early life stress have been associated with hyperactivity of CRF neurons, and direct CRF administration into CNS is associated with depression and anxiety-like symptoms (Gorman et al, 2002). Clinical evidence for the putative role of $\mathrm{CRF}$ in patients with major depression includes (1) increased concentrations of CRF in CSF (Nemeroff et al, 1984); (2) blunted adrenocorticotropin (ACTH) response to systemic injection of exogeneous CRF, suggesting pituitary CRF receptor downregulation due to chronic CRF hypersecretion (Holsboer et al, 1984; Gold et al, 1984); (3) postmortem studies showing increased CRF and/or messenger RNA (mRNA) expression in hypothalamic paraventricular nucleus, brain stem, and frontal cortex (reviewed in Heim et al, in press); and (4) characteristic escape from suppression with elevated ACTH and cortisol response to the combined dexamethasone/CRF test (Ising et al, 2005).

To date, one CRF1 receptor antagonist (R121919) has been tested in an open-label clinical trial for major depression (Zobel et al, 2000), with improvements noted in depressive and anxiety symptoms. Hepatotoxicity ended the clinical development of this particular compound, although several CRF1 receptor antagonists are currently in worldwide development for major depression (see Table 1; Figure 1, pathway h) and for anxiety disorders, including post-traumatic stress disorder and social phobia.

\section{Neurokinin Receptor Antagonists}

Substance $\mathrm{P}$ is the most abundant brain tachykinin (a class, which includes NK A and B among others), and is the endogeneous ligand for the neurokinin 1 (NK-1) receptor (Ebner and Singewald, 2006). The initial interest in this neuropeptide and receptor family for mood and anxiety conditions reflected its extensive colocalization with monoamine neurotransmitters (Ebner et al, 2004) and abundant expression in stress neural circuitry. Genetic or pharmacologic blockade of NK-1 receptors were observed to induce many of the same long-term neural effects as standard antidepressants on cell signaling molecules such as BDNF and hippocampal neurogenesis (Blier et al, 2004; van der
Hart et al, 2005), providing the rationale for experimental therapeutic trials in mood and anxiety disorders (Herpfer and Lieb, 2005). Despite the promising preclinical data, a recent pooled analysis of five 8-week randomized, doubleblind, placebo-controlled, multicenter studies of the NK-1 receptor antagonist aprepitant in over 2500 patients with major depression failed to demonstrate efficacy (Keller et al, 2006). Notably, paroxetine $20 \mathrm{mg}$ was used as an active comparator for three of the trials and demonstrated benefit over placebo on primary outcomes, suggesting that the trials had appropriate assay sensitivity. Despite the setback for this particular compound, several NK-1 antagonists remain in active development for unipolar depression (Table 1).

Saredutant (SR 48968) is a selective non-peptide NK-2 receptor antagonist that blocks the effects of $\mathrm{NK} A$, the endogenous ligand for NK-2. This compound has shown antidepressant and anxiolytic-like effects in preclinical models (Salomé et al, 2006) and has progressed the furthest in clinical development. Of four phase III studies conducted in major depression, two showed statistically significant results and two studies were not statistically significant $v s$ placebo; the drug manufacturer anticipates an application for regulatory approval in 2008 (source: Sanofi-Aventis press release, 17 September 2007).

\section{COMMON INTRACELLULAR PATHWAYS OF MONOAMINERGIC DRUGS AND MOOD STABILIZERS/LITHIUM RELEVANT TO NOVEL THERAPEUTICS}

Evidence that antidepressants and mood stabilizers exert major effects on signaling pathways regulating cellular plasticity has reshaped views about the neurobiological underpinnings of these disorders (Manji et al, 2001; D'Sa and Duman, 2002; Nestler et al, 2002; Schloesser et al, 2008). In this section we review several therapeutic targets and common pathways that monoaminergic antidepressants and mood stabilizers/lithium impact either directly or indirectly, with relevance for novel unipolar and bipolar disorder therapeutics.

\section{BDNF/Growth Factors (Major Depressive Disorder)}

Genetic/neurodevelopmental factors, repeated affective episodes (and likely elevations of glucocorticoids), and illness progression may all contribute to the impairments of cellular resilience, volumetric reductions, and cell death/ atrophy observed in mood disorders (Charney and Manji, 2004). According to the neurotrophic hypothesis of depression (Duman and Monteggia, 2006), decreased expression of BDNF and other growth factors likely contributes to mood disorders, while upregulation of BDNF and its receptor TrkB may be a critical component of all antidepressants' actions (Figure 1, pathway j). Structural imaging studies in unipolar depression have found a decrease in the gray matter volume of multiple areas of the orbital, medial, and dorsolateral prefrontal cortex, with the most prominent reduction reported in the left (but not right) subgenual prefrontal cortex (see Drevets, 2001, 2007). An increase in ventricular size also has been consistently reported in 
patients with bipolar disorder, and progressive gray matter loss in hippocampal, fusiform, and cerebellar regions (Moorhead et al, 2007; see Beyer et al, 2004; Manji et al, 2003 for reviews). The trophic effects are postulated to reverse illness-related atrophic changes, thereby reinstating the neurochemical throughput in critical circuitry regulating affective, cognitive, motoric and neurovegetative functions (Charney and Manji, 2004). Human phase I/II trials of recombinant methionyl human BDNF have already been undertaken, wherein the BDNF was administered by intrathecal infusion to patients with ALS (Ochs et al, 2001). Unfortunately, treatment-limiting side effects were encountered at higher doses, precluding further study. The recent report of dysregulation of several fibroblast growth factor (FGF) system transcripts in frontal cortical regions of brains from human subjects with major depression suggests that this growth factor family may also represent an important target for the development of novel therapeutics (Evans et al, 2004).

\section{Erk MAP Kinase Pathway and Bcl-2 (Bipolar Disorder)}

Lithium and mood stabilizers such as valproate activate the extracellular receptor-coupled kinase (ERK) mitogenactivated protein (MAP) kinase pathway, which is an intracellular signaling cascade implicated in neuroplasticty (Schloesser et al, 2008). An increasing number of strategies are being investigated to develop small-molecule switches for protein-protein interactions, which have the potential to regulate MAP kinase cascades, and interactions between homo- and heterodimers of the Bcl-2 family of proteins (Figure 2, pathway b; see Schloesser et al, 2008 for recent review). Both TrkA and TrkB utilize the phosphatidylinositol-3 kinase (PI3K)/Akt and ERK MAP kinase pathways to bring about their neurotrophic effects (see Schloesser et al, 2008). The ERK MAP kinase cascade also increases the expression of Bcl-2 via its effects on cAMP response element-binding protein (CREB).

It has been hypothesized that lithium's antidepressant effects might be associated with its upregulation of Bcl-2 (Charney and Manji, 2004). Bcl-2 has traditionally been viewed as a 'long-term neuroprotective protein'; however, $\mathrm{Bcl}-2$ is a key regulator of mitochondrial function, and there is a growing appreciation of the diverse functions that mitochondria play in regulating integrated CNS function. Thus, increasing evidence suggests that mitochondrial $\mathrm{Ca}^{2+}$ sequestration has a key role in modulating the tone of synaptic plasticity in a variety of neuronal circuits, and that regulation of mitochondrial function is likely to play an important role in regulating synaptic strength of neuronal circuitry mediating complex behaviors. Bcl-2 attenuates apoptosis by sequestering proforms of death-driving cysteine proteases (called caspases) by preventing the release of mitochondrial apoptogenic factors such as calcium, cytochrome $c$, and apoptosis-inducing factor (AIF) into the cytoplasm, and by enhancing mitochondrial calcium uptake (Charney and Manji, 2004; Schloesser et al, 2008). It is also noteworthy that pramipexole, a drug used in Parkinson's disease, also upregulates Bcl-2 in several brain areas, and has been shown to exert antidepressant effects in a double-blind, placebo-controlled trial in patients with bipolar II depression (Zarate et al, 2004b). While the DA agonistic effects of pramipexole may clearly also contribute to its purported antidepressant effects, its robust neurotrophic effects suggest that it may have broader utility as an antidepressant potentiator.

\section{Phosphodiesterase Inhibitors (Major Depressive Disorder)}

As seen in Figure 1 (pathway a), one approach to enhance the activity of CREB is to use an inhibitor of phosphodiesterase (PDE), the enzyme responsible for the breakdown of CAMP. Indeed, PDE4A and PDE4B may be relevant targets for development of agents that possess antidepressant effects either as monotherapy or in combination with agents that increase intrasynaptic monoamine levels, due to the possible synergism of effects on the cAMP cascade. The idea that PDE inhibitors may have potential antidepressant activity is not a new one, and was initially proposed by Wachtel in the early 1980s (Wachtel and Schneider, 1986). In the 1980s and early 1990s, a number of open-label and controlled clinical trials demonstrated that rolipram, a specific inhibitor of the high-affinity cAMP PDE4, may have antidepressant efficacy in depressed patients (reviewed in Manji et al, 2003). In addition, there is some evidence that rolipram may have a faster onset of response compared with standard antidepressants. Despite these data, the potential use of rolipram for depression was limited because of side effects such as nausea and emesis. Second-generation compounds with markedly improved tolerability are being developed (Dyke and Montana, 2002; Huang et al, 2001), and it is anticipated that the availability of CNS-penetrant PDE4 inhibitors may lead to the development of a novel class of antidepressants.

\section{Glycogen Synthase Kinase-3 (Bipolar Disorder and Major Depression)}

Glycogen synthase kinase-3 (GSK-3) is a ubiquitous, constitutively active, multi-substrate serine/threonine kinase that regulates, and is regulated by, numerous diverse signaling pathways (eg, the Wnt pathway, PI3K pathway, protein kinase $\mathrm{A}$, protein kinase $\mathrm{C}$, among many others; Doble and Woodgett, 2003; see Figure 2). Initial interest in GSK-3 as a therapeutic target for mood disorders arose from the seminal observations that lithium directly inhibited the enzyme (Klein and Melton, 1996; Figure 1, pathway $j$, while more recent data have highlighted the important role of GSK-3 regulation in the pathophysiology of mood disorders (see O'Brien and Klein, 2007; Gould and Manji, 2005; Gould et al, 2006 and references therein). Major findings relevant to both pathophysiology and potential therapeutic mechanisms of action include:

(i) GSK-3 phosphorylation is markedly regulated by agents that increase 5-HT transmission such as d-fenfluramine, fluoxetine, and imipramine such that inhibitory control of GSK-3 might occur in mood disorders marked by 5-HT dysregulation (Li et al, 2004).

(ii) GSK-3 is a major regulator of apoptosis and cellular plasticity/resilience (Crowder and Freeman, 2000; Liu et al, 2004; Franco et al, 2004; Zhao et al, 2007). Generally, increased activity of GSK-3 is proapoptotic, 


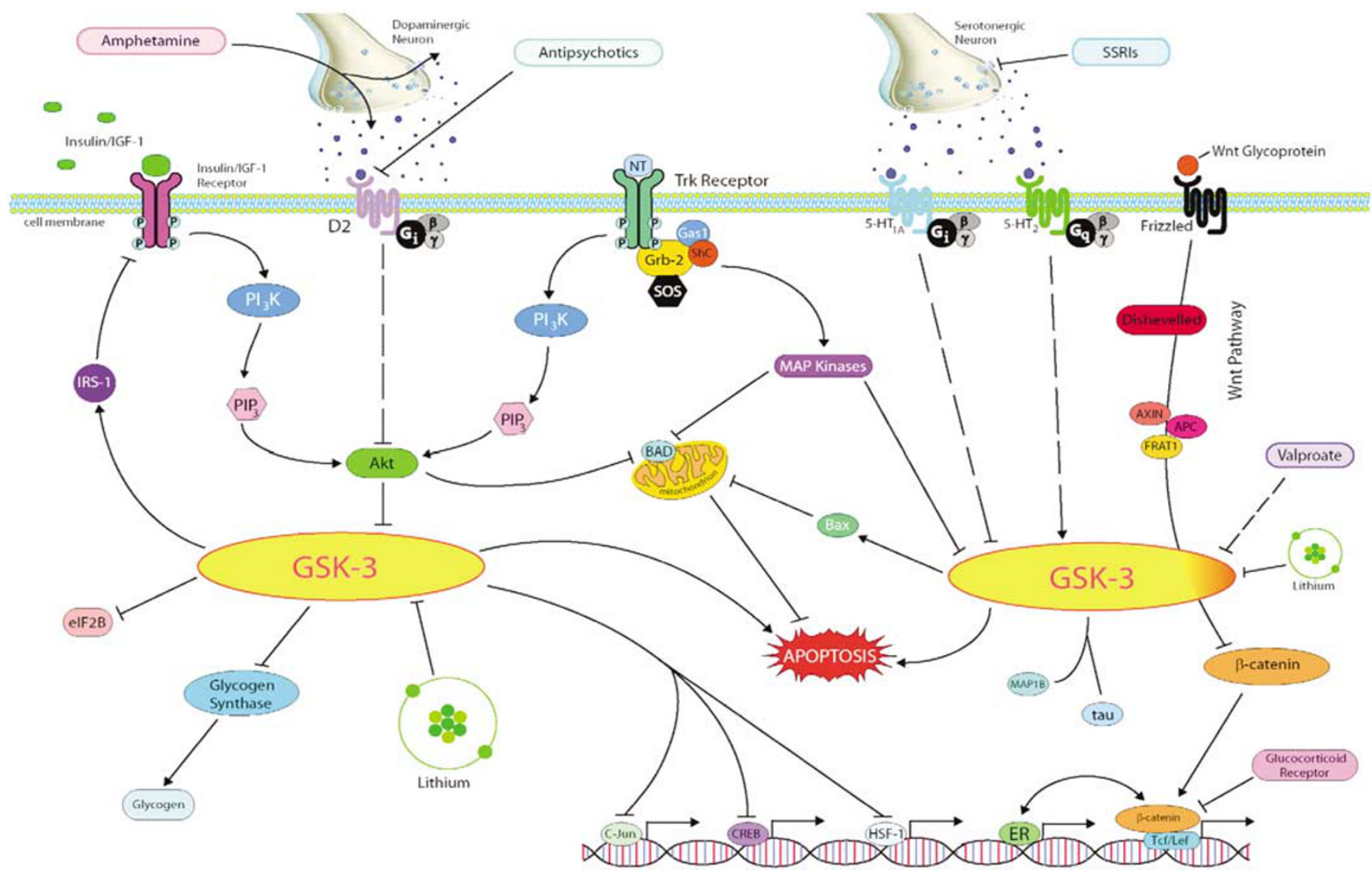

Figure 2 GSK-3 and intracellular signaling. GSK-3 regulates diverse signaling pathways in the cell. These include insulin/insulin-like growth factor (IGF-I) signaling, neurotrophic factor signaling, and Wnt signaling. Insulin signaling through its tyrosine receptor kinase (Trk) receptor activates PI3K-mediated signaling, resulting in inhibition of GSK-3. Inhibition of GSK-3 activates glycogen synthase and eukaryotic initiation factor 2B (elF2B), while inhibiting insulin receptor substrate-I (IRS-I, an inhibitor of the insulin receptor). Insulin is generally thought to have minimal effects on CNS neurons; however, IGF-I interacting with its cognate receptor appears to have similar functions. Neurotrophins (NT) act through Trk receptors A, B, and C to activate PI3K, AKT, and inhibit GSK-3. Many effectors have been implicated in GSK-3's neurotrophic effects, including transcription factors (eg, heat-shock factor-I (HSF-I), C-Jun, and CREB) and, recently, the proapoptotic Bcl-2 family member BAX. In the Wnt-signaling pathway, secreted Wnt glycoproteins interact with the frizzled family of receptors and, through disheveled-mediated signaling, inhibit GSK-3. Stability of this process requires the scaffolding proteins AXIN and adenomatous polyposis coli (APC). Normally active GSK-3 phosphorylates $\beta$-catenin, leading to its ubiquitin-dependent degradation. However, when GSK-3 is inhibited in the Wnt pathway, $\beta$-catenin is not degraded, allowing for its interaction with T cell-specific transcription factor (TCF) to act as a transcription factor. $\beta$-Catenin activity is modulated by the intracellular estrogen receptor (ER), which also affects transcription of an independent set of genes. As shown in the figure and described in the text, medications useful for the treatment of mood disorders have both direct and indirect effects on GSK-3, and GSK-3regulated cell signaling pathways. This includes direct effects of lithium and indirect effects of antipsychotics, amphetamine, and selective 5-HT SSRIs. These distinct pathways have convergent effects on cellular processes such as bioenergetics (energy metabolism), neuroplasticity, neurogenesis, resilience, and survival. Thus, our hypothesis is that lithium (and other medications) may act by enhancing these processes through inhibition of GSK-3. $\mathrm{G}_{\mathrm{i}}$ refers to $\mathrm{G}_{\mathrm{i}} / \mathrm{G}_{\mathrm{o}}$; $\mathrm{G}_{\mathrm{q}}$ refers to $\mathrm{G}_{\mathrm{q}} / \mathrm{G}_{1}$. Modified and reproduced with permission from Gould and Manji (2005).

whereas inhibiting GSK-3 attenuates or prevents apoptosis (see Gould et al, 2006 for review).

(iii) GSK-3 has a major effect on regulating the circadian period in diverse species, an effect it shares with lithium (Gould et al, 2004b). Notably, treatment strategies are being developed derived from a chronobiological model of bipolar disorder (McClung, 2007) based on evidence that the central transcriptional activator of molecular rhythms, CLOCK, may play an important role in the DA system for mood regulation (Roybal et al, 2007).

(iv) Recent animal behavioral data (from pharmacologic and genetic models) have shown that manipulation of the GSK-3-signaling cascade produces both antidepressant and antimanic effects in models of depression or mania. Two separate GSK-3 inhibitors (AR-A014418;
Gould et al, 2004a and L803-mts; Kaidanovich-Beilin et al, 2004) were found to reduce immobility in the forced swim test and attenuate amphetamine-induced hyperactivity. Animals lacking one copy of the GSK-3 $\beta$ gene demonstrate specific behavioral responses to lithium and other GSK-3 inhibitors (Beaulieu et al, 2004; O'Brien et al, 2004), while transgenic overexpression of GSK was associated with increased activity (Prickaerts et al, 2006). This is one of the few manipulations that have been shown to exert both antidepressant and antimanic effects, with two caveats. First, it is not unanimously accepted that amphetamineinduced hyperactivity is a valid model of manic behavior. Second, there is evidence that rolipram (discussed above) also decreases methamphetamineinduced hyperlocomotion (Siuciak et al, 2007). 
(v) An increase in GSK-3 $\beta$ activity was observed recently in patients with major depression in a postmortem study (Karege et al, 2007), and response to lithium augmentation in major depression was associated with the GSK-3 $\beta-50 \mathrm{~T} / \mathrm{C}$ single-nucleotide polymorphism (Adli et al, 2007).

In view of their potential therapeutic effects not only in bipolar disorder, but also in Alzheimer's disease (Huang and Klein, 2006) and diabetes (Henriksen and Dokken, 2006), it is not surprising that specific, brain-penetrant GSK-3 inhibitors are in development by numerous pharmaceutical companies. GSK-3 phosphorylates and inhibits glycogen synthase, a downstream effector of insulin action, and overactivity of GSK-3 is associated with insulin resistance of skeletal muscle glucose transport (Schloesser et al, 2008); accordingly, GSK-3 inhibitors have been tested in prediabetic and type 2 diabetes rodent models (Henriksen and Dokken, 2006). Unless side effects prove to be prohibitive, GSK-3 inhibitors may thus represent a completely novel class of treatment for severe mood disorders, germane to both disease pathophysiology as well as to understanding the mechanism of action of existing treatments (Gould and Manji, 2005; Gould et al, 2006).

\section{Protein Kinase C-Signaling Cascade (Bipolar Disorder)}

PKC is a shared biochemical target for the actions of chronic lithium and valproate. PKC is highly enriched in the brain, where it plays a major role in regulating both preand postsynaptic aspects of neurotransmission. PKC is now known to exist as a family of closely related subspecies, has a heterogeneous distribution in brain (with particularly high levels in presynaptic nerve terminals), and plays a major role in the regulation of neuronal excitability, neurotransmitter release, and long-term alterations in gene expression and plasticity (Manji and Lenox, 1999). A considerable amount of biochemical data support the potential involvement of PKC in the pathophysiology and treatment of bipolar disorder. Evidence supporting this are changes in PKC and its substrates in bipolar patients, and changes in PKC-signaling pathways after treatment with lithium or valproate (Manji and Lenox, 1999). It is noteworthy that psychostimulants, which are capable of triggering manic episodes in susceptible individuals, and induce manic-like behaviors in rodents, are known to activate PKC. Thus, the evidence suggests that two structurally dissimilar antimanic agents-lithium and valproate - attenuate PKC function in a therapeutically relevant time frame, while pro-manic psychostimulants activate PKC. These data suggest that PKC modulation plays a critical role in the treatment of mania. Birnbaum et al (2004) demonstrated that excessive activation of PKC dramatically impaired the cognitive functions of the prefrontal cortex, exposure to stress-activated PKC, and resulted in prefrontal dysfunction, and inhibition of PKC (including indirectly with mood stabilizers) protected cognitive function. Pharmacological inhibition of PKC results in many behavioral changes similar to the ones induced by mood stabilizers. These include attenuation of hyperactivity, risk-taking behavior, and hedonic drive; notably, PKC inhibitors attenuate these important aspects of the manic-like syndrome in rodents (Einat and Manji, 2006; Einat et al, 2007). Importantly, recent preclinical studies have specifically investigated the antimanic effects of tamoxifen per se (since this is the only CNS-penetrant PKC inhibitor available for humans). These studies showed that tamoxifen significantly reduced amphetamine-induced hyperactivity and risk-taking behavior (Einat et al, 2007). Notably, a recent whole-genome association study of BPD has further implicated this pathway. Of the risk genes identified, the one demonstrating by far the strongest association with BPD was diacylglycerol kinase, an immediate regulator of PKC (Baum et al, 2007). These findings led to a single-blind clinical trial investigating possible antimanic properties of the PKC inhibitor tamoxifen (Bebchuk et al, 2000). While best known for its antiestrogen properties, tamoxifen is also a potent PKC inhibitor at high concentrations. Initial results are encouraging, finding that tamoxifen treatment resulted in a significant decrease in manic symptoms (Bebchuk et al, 2000). Larger double-blind, placebo-controlled studies of tamoxifen conducted at NIMH have shown that tamoxifen indeed possesses robust antimanic effects. Subjects on tamoxifen showed significant improvement in mania compared with placebo as early as 5 days, and the effect size for the drug difference was very large after 3 weeks (Zarate et al, 2007b). PKC has multiple isoforms and PKCmediated cellular processes are tissue- and isoform specific. This has allowed the modulation of function of individual isozymes; thus, compounds with isozyme selectivity may find themselves in the therapeutic armamentarium for bipolar disorder, although to date no such compounds have been tested in bipolar disorder (Zarate et al, 2006b).

\section{CONCLUSION}

Significant paradigm shifts in the psychopharmacology of mood disorders have not occurred in the past several decades, due to poor understanding of disease pathogenesis, imprecise delineation of phenotypic boundaries, and limitations of animal models (Berton and Nestler, 2006). While serendipity will continue to play a role in drug discovery in psychiatry, advances in animal and human genetics, molecular biology, and brain imaging will likely advance the discovery of biomarkers and identify plausible endophenotypes for subgroups of patients with these illnesses. Drugs used commonly in other medical specialties will continue to be explored in mood disorders, based on molecular understanding of their actions. As a prominent recent example, the commonly used $\beta$-lactam class of antibiotics were found to increase glutamate uptake via increased expression of glial glutamate transporter (Glt1), thus providing a novel class of compounds that may act to buffer increased glutamatergic release in stress-related conditions (Rothstein et al, 2005).

A major thrust of future drug discovery in mood disorders will continue efforts to identify agents with rapid and sustained onsets of action (such as i.v. ketamine and other NMDA receptor-selective subtype antagonists), thereby minimizing disorder morbidity and mortality in the critical weeks between initial symptom expression and drug efficacy. The development of novel PET radioligands 
for neurotransmitter receptors not extensively investigated to date (eg, nicotinic and muscarinic cholinergic systems) will shed light on an older literature suggesting that cholinomimetic drugs (ie, muscarinic agonists, acetylcholinesterase inhibitors) exacerbate depressive signs and symptoms such as dysphoria, psychomotor retardation, impairment of attention and memory, HPA axis hyperactivity, and sleep EEG abnormalities (Bertrand, 2005). In a proof-of-concept study, an older antimuscarinic drug, scopolamine $(4 \mu \mathrm{g} / \mathrm{kg})$, was observed to produce potent reductions in depressive severity compared with placebo, with rapid, robust antidepressant responses achieved in 18 patients with unipolar or bipolar depression (Furey and Drevets, 2006).

Finally, while drug discovery efforts have generally focused on specific neurotransmitter receptors or transporters as the target of intervention, there are many additional areas (eg, trafficking proteins, immune modulators) that have not been considered due to space limitations. Next-generation drugs, in addition to treating core symptoms of mood disorders, might be able to target additional important components of these conditions such as enhancing cognition (eg AMPA receptor potentiators), preventing or reversing epigenetic factors that may have long-term negative impact on the course of the illness (eg, histone deacetylase inhibitors), or reducing medical comorbidities such as diabetes (eg, GSK-inhibitors).

\section{ACKNOWLEDGEMENTS}

Supported by NIMH Career Development Award K23MH0 69656, U19-MH-069056, National Alliance for Research in Schizophrenia and Depression, and General Clinical Research Center at Mount Sinai School of Medicine. We thank Gerard Sanacora, MD, PhD, and Carlos Zarate, MD, for their valuable contributions to this work, and Kate Collins, LMSW and Jackie Penn for editorial assistance.

\section{DISCLOSURE/CONFLICT OF INTEREST}

Dr Mathew has received compensation over the last three years from AstraZeneca, Cephalon Inc., Pfizer Pharmaceuticals, and Takeda Industries. He has received research grant support from Alexza Pharmaceuticals, Novartis, and Predix Pharmaceuticals. Dr Mathew and Charney have been named as inventors on a use-patent of ketamine for the treatment of depression. If ketamine were shown to be effective in the treatment of depression and received approval from the Food and Drug Administration (FDA) for this indication, Drs Mathew and Charney could benefit financially.

Dr Manji: A patent application for the use of ketamine in depression has been submitted listing Dr Manji among the inventors. Dr Manji has assigned his rights on the patent to the US government.

Dr Charney has received compensation over the last three years from AstraZeneca, Bristol-Myers Squibb Company, Cyberonics, Forest Laboratories Inc., GeneLogic Inc., Institute of Medicine, Neuroscience Education Institute, Novartis Pharmaceuticals Corporation, Organon International Inc., and Quintiles Inc.

\section{REFERENCES}

Adli M, Hollinde DL, Stamm T, Wiethoff K, Tsahuridu M, Kirchheiner J et al (2007). Response to lithium augmentation in depression is associated with the glycogen synthase kinase 3-Beta-50T/C single nucleotide polymorphism. Biol Psychiatry 62: 1295-1302.

Agid Y, Buzsaki G, Diamond DM, Frackowiak R, Giedd J, Girault J-A et al (2007). How can drug discovery for psychiatric disorders be improved? Nat Rev Drug Discov 6: 189-201.

Baum A, Akula N, Cabenero M, Cardona I, Corona W, Klemens B et al (2007). A genome-wide association study implicates diacylglycerol kinase eta (DGKH) and several other genes in the etiology of bipolar disorder. Mol Psychiary; e-pub ahead of print; May 8, 2007; advance online publication; doi:10.1038/ sj.mp.4002012.

Beaulieu JM, Sotnikova TD, Yao WD, Kockeritz L, Woodgett JR, Gainetdinov RR et al (2004). Lithium antagonizes dopaminedependent behaviors mediated by an AKT/glycogen synthase kinase 3 signaling cascade. Proc Natl Acad Sci USA 101: 5099-5104.

Bebchuk JM, Arfken CL, Dolan-Manji S, Murphy J, Hasanat K, Manji $H$ (2000). A preliminary investigation of a protein kinase $\mathrm{C}$ inhibitor in the treatment of acute mania. Arch Gen Psychiatry 57: 95-97.

Berman RM, Cappiello A, Anand A, Oren DA, Heninger GR, Charney DS et al (2000). Antidepressant effects of ketamine in depressed patients. Biol Psychiatry 47: 351-354.

Berton O, Nestler EJ (2006). New approaches to antidepressant drug discovery: beyond monoamines. Nat Rev Neurosci 7: 137-151.

Bertrand D (2005). The possible contribution of neuronal nicotinic acetylcholine receptors in depression. Dialogues Clin Neurosci 7: 207-216.

Beyer JL, Kuchibhatla M, Payne ME, Moo-Young M, Cassidy F, Mcfall J et al (2004). Hippocampal volume measurement in older adults with bipolar disorder. Am J Geriatr Psychiatry 12: 613-620.

Bhagwagar Z, Hinz R, Taylor M, Fancy S, Cowen P, Grasby P (2006). Increased 5-HT (2A) receptor binding in euthymic, medication-free patients recovered from depression: a positron emission study with [(11)C]MDL 100,907. Am J Psychiatry 163: 1580-1587.

Birnbaum SG, Yuan PX, Wang M, Vijayraghavan S, Bloom AK, Davis DJ et al (2004). Protein kinase C overactivity impairs prefrontal cortical regulation of working memory. Science 306: 882-884.

Bleakman D, Alt A, Witkin JM (2007). AMPA receptors in the therapeutic management of depression. CNS Neurol Disord Drug Targets 6: 117-126.

Blier P, Gobbi G, Haddjeri N, Santarelli L, Mathew G, Hen R 2004. Impact of substance $\mathrm{P}$ receptor antagonism on the serotonin and norepinephrine systems: relevance to the antidepressant/anxiolytic response. J Psychiatry Neurosci 29: 208-218.

Boyer PA, Skolnick P, Fossom LH (1998). Chronic administration of imipramine and citalopram alters the expression of NMDA receptor subunit mRNAs in mouse brain. A quantitative in situ hybridization study. J Mol Neurosci 10: 219-233.

Brandoli C, Sanna A, De Bernardi MA, Follesa P, Brooker G, Mocchetti I (1998). Brain-derived neurotrophic factor and basic fibroblast growth factor downregulate NMDA receptor function in cerebellar granule cells. J Neurosci 18: 7953-7961.

Charney DS, Manji HK (2004). Life stress, genes, and depression: multiple pathways lead to increased risk and new opportunities for intervention. Science STKE 225: 1-11.

Choudary PV, Molmar M, Evans SJ, Tomita H, Li JZ, Vawter MP et al (2005). Altered cortical glutamatergic and GABAergic signal transmission with glial involvement in depression. Proc Natl Acad Sci USA 102: 15653-15658. 
Crowder RJ, Freeman RS (2000). Glycogen synthase kinase-3 beta activity is critical for neuronal death caused by inhibiting phosphatidylinositol 3-kinase or Akt but not for death caused by nerve growth factor withdrawal. J Biol Chem 275: 34266-34271.

Doble BW, Woodgett JR (2003). GSK-3: tricks of the trade for a multi-tasking kinase. J Cell Sci 116: 1175-1186.

Drevets WC (2001). Neuroimaging and neuropathological studies of depression: implications for the cognitive-emotional features of mood disorders. Curr Opin Neurobiol 11: 240-249.

Drevets WC (2007). Orbitofrontal cortex function and structure in depression. Ann NY Acad Sci, September 13; e-pub ahead of print.

D'Sa C, Duman RS (2002). Antidepressants and neuroplasticity. Bipolar Disord 4: 183-194.

Du J, Machado-Vieira R, Maeng S, Martinowich K, Manji HK, Zarate CA (2006). Enhancing AMPA to NMDA throughput as a convergent mechanism for antidepressant action. Drug Discov Today: Therapeutic Strategies 3: 519-526.

Du J, Suzuki K, Wei Y, Wang Y, Blumenthal R, Chen Z et al (2007). The anticonvulsants lamotrigine, riluzole, and valproate differentially regulate AMPA receptor membrane localization: relationship to clinical effects in mood disorders. Neuropsychopharmacology 32: 793-802.

Duman RS, Monteggia LM (2006). A neurotrophic model for stress-related mood disorders. Biol Psychiatry 59: 1116-1127.

Dunlop BW, Nemeroff CB (2007). The role of dopamine in the pathophysiology of depression. Arch Gen Psychiatry 64: 327-337.

Dyke HJ, Montana JG (2002). Update on the therapeutic potential of PDE4 inhibitors. Expert Opin Invest Drugs 11: 1-13.

Ebner K, Rupniak NM, Saria A, Singewald N (2004). Substance P in the medial amygdala: emotional stress-sensitive release and modulation of anxiety-related behavior in rats. Proc Natl Acad Sci USA 101: 4280-4285.

Ebner K, Singewald N (2006). The role of substance P in stress and anxiety responses. Amino Acids 31: 251-272.

Einat H, Manji HK (2006). Cellular plasticity cascades: genes-tobehavior pathways in animal models of bipolar disorder. Biol Psychiatry 59: 1160-1171.

Einat H, Yuan PX, Szabo ST, Dogra S, Manji HK (2007). Protein kinase $\mathrm{C}$ inhibition antagonizes several facets of manic-like behaviors: implications for the development of novel therapeutics for bipolar disorder. Neuropsychobiology 55: 123-131.

Evans SJ, Choudary PV, Neal CR, Li JZ, Vawter MP, Tomita H et al (2004). Dysregulation of the fibroblast growth factor system in major depression. Proc Natl Acad Sci USA 101: 15506-15511.

Fava M, Alpert JE, Carmin CN, Wisniewski SR, Trivedi MH, Biggs $\mathrm{MM}$ et al (2004). Clinical correlates and symptom patterns of anxious depression among patients with major depressive disorder in STAR ${ }^{\star}$ D. Psychol Med 34: 1299-1308.

Fava M, Rush AJ, Alpert JE, Carmin CN, Balasubramani GK, Wisniewski SR et al (2006). What clinical and symptom features and comorbid disorders characterize outpatients with anxious major depression? Can J Psychiatry 51: 823-835.

Franco B, Bogdanik L, Bobinnec Y, Debec A, Bockaert J, Parmentier ML et al (2004). Shaggy, the homolog of glycogen synthase kinase 3, controls neuromuscular growth in Drosophila. J Neurosci 24: 6573-6577.

Furey ML, Drevets WC (2006). Antidepressant efficacy of the antimuscarinic drug scopolamine: a randomized, placebocontrolled clinical trial. Arch Gen Psychiatry 63: 1121-1129.

Gil R, Alanine A, Bourson A, Buttelmann B, Fischer G, Heitz MP et al (2002). Pharmacological characterization of Ro 63-1908 (1[2-(4-hydroxy-phenoxy)-ethyl]-4-(4-methyl-benzyl)-piperidine4-ol), a novel subtype-selective $N$-methyl-D-aspartate antagonist. J Pharmacol Exp Ther 302: 940-948.
Gold PW, Chrousos G, Kellner C, Post R, Roy A, Augerinos P et al (1984). Psychiatric implications of basic and clinical studies with corticotropin-releasing factor. Am J Psychiatry 141: 619-627.

Gorman JM, Mathew S, Coplan J (2002). Neurobiology of early life stress: nonhuman primate models. Semin Clin Neuropsych 7: 96-103.

Gould TD, Einat H, Bhat R, Manji HK (2004a). AR-A014418, a selective GSK-3 inhibitor, produced antidepressant-like effects in the forced swim test. Int J Neuropsychopharmacol 7: 387-390.

Gould TD, Manji HK (2005). Glycogen synthase kinase-3: a putative molecular target for lithium mimetic drugs. Neuropsychopharmacology 30: 1223-1237.

Gould TD, Picchini AM, Einat H, Manji HK (2006). Targeting glycogen synthase kinase-3 in the CNS: implications for the development of new treatments for mood disorders. Curr Drug Targets 7: 1399-1409.

Gould TD, Quiroz JA, Singh J, Zarate CA, Manji HK (2004b). Emerging experimental therapeutics for bipolar disorder: insights from the molecular and cellular actions of current mood stabilizers. Mol Psychiatry 9: 734-755.

Hamidi M, Drevets WC, Price JL (2004). Glial reduction in amygdala in major depressive disorder is due to oligodendrocytes. Biol Psychiatry 55: 563-569.

Hasler G, Drevets WC, Manji HK, Charney DS (2004). Discovering endophenotypes for major depression. Neuropsychopharmacology 29: 1765-1781.

He Y, Benz A, Fu T, Wang M, Covey DF, Zorumski CF et al (2002). Neuroprotective agent riluzole potentiates postsynaptic $\mathrm{GABA}_{\mathrm{A}}$ receptor function. Neuropharmacology 42: 199-209.

Heim C, Mletzko T, Purselle D, Musselman DL, Nemeroff CB (2007). The dexamethasone/corticotropin-releasing factor test in men with major depression: role of childhood trauma. Biol Psychiatry, September 6; e-pub ahead of print.

Henriksen EJ, Dokken BB (2006). Role of glycogen synthase kinase- 3 in insulin resistance and type 2 diabetes. Curr Drug Targets 7: 1435-1441.

Herpfer I, Lieb K (2005). Substance P receptor antagonists in psychiatry: rationale for development and therapeutic potential. CNS Drugs 19: 275-293.

Holsboer F (2000). The corticosteroid receptor hypothesis of depression. Neurospychopharmacology 23: 477-501.

Holsboer F, Von Bardeleben U, Gerken A, Stalla GK, Muller OA (1984). Blunted corticotropin and normal cortisol response to human corticotropin-releasing factor in depression. $N$ Engl $J$ Med 311: 1127.

$\mathrm{Hu}$ X-Z, Rush AJ, Charney D, Wilson AF, Sorant AJM, Papanicolaou GJ et al (2007). Association between a functional serotonin transporter polymorphism and citalopram treatment in adult outpatients with major depression. Arch Gen Psychiatry 64: 783-792.

Huang HC, Klein PS (2006). Multiple role for glycogen synthase kinase-3 as a drug target in Alzheimer's disease. Curr Drug Targets 7: 1389-1397.

Huang Z, Ducharme Y, Macdonald D, Robichaud A (2001). The next generation of PDE4 inhibitors. Curr Opin Chem Biol 5: 432-438.

Ising M, Kunzel HE, Binder EB, Nickel T, Modell S, Holsboer F (2005). The combined dexamethasone/CRH test as a potential surrogate marker in depression. Prog Neuropsychopharmacol Biol Psychiatry 29: 1085-1093.

Kaidanovich-Beilin O, Milman A, Weizman A, Pick CG, Eldar-Finkelman H (2004). Rapid antidepressant-like activity of specific glycogen synthase kinase-3 inhibitor and its effect on beta-catenin in mouse hippocampus. Biol Psychiatry 55: 781-784.

Karege F, Perroud N, Burkhardt S, Schwald M, Ballmann E, La Harpe $\mathrm{R}$ et al (2007). Alteration in kinase activity but not in protein levels of protein kinase $B$ and glycogen synthase 
kinase- $3 \beta$ in ventral prefrontal cortex of depressed suicide victims. Biol Psychiatry 61: 240-245.

Katoh-Semba R, Asano T, Ueda H, Morishita R, Takeuchi IK, Inaguma $\mathrm{Y}$ et al (2002). Riluzole enhances expression of brainderived neurotrophic factor with consequent proliferation of granule precursor cells in the rat hippocampus. FASEB J 16: $1328-1330$.

Keller MB (2004). Remission versus response: the new gold standard of antidepressant care. J Clin Psychiatry 65(Suppl 4): 53-59.

Keller MB, Montgomery S, Ball W, Morrison M, Snavely D, Liu G et al (2006). Lack of efficacy of the substance P (Neurokinin1 receptor) antagonist aprepitant in the treatment of major depressive disorder. Biol Psychiatry 59: 216-223.

Kessler RC, Berglund P, Demler O, Jin R, Merikangas KR, Walters EE (2005). Lifetime prevalence and age-of-onset distributions of DSM-IV Disorders in the National Comorbidity Survey Replication. Arch Gen Psychiatry 62: 593-602.

Klein PS, Melton DA (1996). A molecular mechanism for the effect of lithium on development. Proc Natl Acad Sci USA 93: 8455-8459.

Krystal JH (2007). Ketamine and the potential role for rapid-acting antidepressant medications. Swiss Med Wkly 137: 215-216.

Kugaya A, Sanacora G (2005). Beyond monoamines: glutamatergic function in mood disorders. CNS Spectr 10: 808-819.

Li X, Zhu W, Roh MS, Friedman AB, Rosborough K, Jope RS (2004). In vivo regulation of glycogen synthase kinase-3beta (GSK3beta) by serotonergic activity in mouse brain. Neuropsychopharmacology 29: 1426-1431.

Liu S, Yu S, Hasegawa Y, Lapushin R, Xu HJ, Woodgett JR et al (2004). Glycogen synthase kinase 3beta is a negative regulator of growth factor-induced activation of the c-Jun N-terminal kinase. J Biol Chem 279: 51075-51081.

Maeng S, Zarate CA, Du J, Chen G, Manji HK (2007). Cellular mechanisms underlying the antidepressant effects of ketamine: role of AMPA receptors. Biol Psychiatry Jul 20; e-pub ahead of print.

Maj J, Klimek V, Golembiowska K, Rogóz Z, Skuza G (1993). Central effects of repeated treatment with CGP 37849, a competitive NMDA receptor antagonist with potential antidepressant activity. Pol J Pharmacol 45: 455-466.

Manji HK, Drevets WC, Charney DS (2001). The cellular neurobiology of depression. Nat Med 7: 541-547.

Manji HK, Lenox RH (1999). Ziskind-Somerfeld Research Award. Protein kinase $\mathrm{C}$ signaling in the brain: molecular transduction of mood stabilization in the treatment of manic-depressive illness. Biol Psychiatry 46: 1328-1351.

Manji HK, Quiroz JA, Sporn J, Payne JL, Denicoff K, A Gray N et al (2003). Enhancing neuronal plasticity and cellular resilience to develop novel, improved therapeutics for difficult-to-treat depression. Biol Psychiatry 53: 707-742.

Mann JJ (2005). The medical management of depression. $N$ Engl J Med 353: 1819-1834.

Martinowich K, Manji H, Lu B (2007). New insights into BDNF function in depression and anxiety. Nat Neurosci 10: 1089-1093.

Mason GF, Petersen KF, de Graaf RA, Shulman GI, Rothman DL (2007). Measurements of the anaplerotic rate in the human cerebral cortex using 13C magnetic resonance spectroscopy and [1-13C] and [2-13C] glucose. J Neurochem 100: 73-86.

Mathew SJ, Amiel JA, Coplan JD, Fitterling H, Sackeim HA, Gorman JM (2005a). Riluzole in generalized anxiety disorder. Am J Psychiatry 162: 2379-2381.

Mathew SJ, Keegan K, Smith L (2005b). Experimental therapeutics for mood disorders: focus on glutamate modulators. Braz J Psych 27: $243-248$.

Mathew SJ, Price RB, Mao X, Smith ELP, Coplan JD, Charney DS et al Hippocampal $\mathrm{N}$-acetylaspartate concentration and response to riluzole in generalized anxiety disorder. Biol Psychiatry October 27; e-pub ahead of print.
McClung CA (2007). Circadian genes, rhythms and the biology of mood disorders. Pharmacol Ther 114: 222-232.

McNally GP, Lee BW, Chiem JY, Choi EA (2005). The midbrain periaqueductal gray and fear extinction: opioid receptor subtype and roles of cyclic AMP, protein kinase A, and mitogen-activated protein kinase. Behav Neurosci 119: 1023-1033.

Meyer JH, Ginovart N, Boovariwala A, Sagrati S, Hussey D, Garcia A et al (2006). Elevated monoamine oxidase A levels in the brain: an explanation for the monoamine imbalance of major depression. Arch Gen Psychiatry 63: 1209-1216.

Miller RG, Mitchell JD, Lyon M, Moore DH (2007). Riluzole for amyotrophic lateral sclerosis (ALS)/motor neuron disease (MND). Cochrane Database Syst Rev: Art. No. CD001447 (Suppl 1) doi: 10.1002/14651858.CD001447.pub2.

Mizuta I, Ohta M, Ohta K, Nishimura M, Mizuta E, Kuno S (2001). Riluzole stimulates nerve growth factor, brain-derived neurotrophic factor and glial cell line-derived neurotrophic factor synthesis in cultured mouse astrocytes. Neurosci Lett 310: 117-120.

Moffitt TE, Harrington H, Caspi A, Kim-Cohen J, Goldberg D, Gregory AM et al (2007). Depression and generalized anxiety disorders: cumulative and sequential comorbidity in a birth cohort followed prospectively to age 32 years. Arch Gen Psychiatry 64: 651-660.

Moorhead TWJ, McKirdy J, Sussmann JED, Hall J, Lawrie SM, Johnsone EC et al (2007). Progressive gray matter loss in patients with bipolar disorder. Biol Psychiatry, print copy in press (originally published online at www.sobp.org /doi:10.1016/ jbiopsych.2007.03.005).

Moses-Kolko EL, Price JC, Thase ME, Meltzer CC, Kupfer DJ, Mathis CA et al (2007). Measurement of 5-HT1A receptor binding in depressed adults before and after antidepressants drug treatment using positron emission tomography and [11C]WAY-100635. Synapse 61: 523-530.

Nemeroff C, Widerlöv E, Bissette G, Walléus H, Karlsson I, Eklund $\mathrm{K}$ et al (1984). Elevated concentrations of CSF corticotropinreleasing factor-like immunoreactivity in depressed patients. Science 226: 1342-1344.

Nestler EJ, Barrot M, DiLeone RJ, Eisch AJ, Gold SJ, Monteggia LM (2002). Neurobiology of depression. Neuron 34: 13-25.

Nestler EJ, Carlezon WA (2006). The mesolimbic dopamine reward circuit in depression. Biol Psychiatry 59: 1151-1159.

O'Brien WT, Harper AD, Jove F, Woodgett JR, Maretto S, Piccolo S et al (2004). Glycogen synthase kinase-3beta haploinsufficiency mimics the behavioral and molecular effects of lithium. J Neurosci 24: 6791-6798.

O'Brien WT, Klein PS (2007). Regulation of glycogen synthase kinase-3 in patients with affective disorders. Biol Psychiatry 61: $139-141$.

Ochs G, Penn RD, York M, Giess R, Beck M, Tonn J et al (2001). A phase I/II trial of recombinant methionyl human brain derived neurotrophic factor administered by intrathecal infusion to patients with amyotrophic lateral sclerosis. Amyotroph Lateral Scler Other Motor Neuron Disord 1: 201-206.

Olney JW, Labruyere J, Price MT (1989). Pathological changes induced in cerebrocortical neurons by phencyclidine and related drugs. Science 244: 1360-1362.

Oquendo MA, Hastings RS, Huang YY, Simpson N, Ogden RT, $\mathrm{Hu} \mathrm{XZ}$ et al (2007). Brain serotonin transporter binding in depressed patients with bipolar disorder using positron emission tomography. Arch Gen Psychiatry 64: 201-208.

Pangalos MN, Schechter LE, Hurko O (2007). Drug development for CNS disorders: strategies for balancing risk and reducing attrition. Nat Rev Drug Discov 6: 521-532.

Papp M, Klimek V, Willner P (1994). Effects of imipramine on serotonergic and beta-adrenergic receptor binding in a realistic animal model of depression. Psychopharmacology (Berl) 114: 309-314. 
Parsey RV, Hastings RS, Oquendo MA, Huang YY, Simpson N, Arcement $\mathrm{J}$ et al (2006a). Lower serotonin transporter binding potential in the human brain during major depressive episodes. Am J Psychiatry 163: 52-58.

Parsey RV, Oquendo MA, Ogden TR, Olvet DM, Simpson N, Huang YY et al (2006b). Altered serotonin 1A binding in major depression: a [carbonyl-C-11] Way100635 Positron Emission Tomography Study. Biol Psychiatry 59: 106-113.

Paul IA, Trullas R, Skolnick P, Nowak G (1992). Down-regulation of cortical beta-adrenoceptors by chronic treatment with functional NMDA antagonists. Psychopharmacology 106: 285-287.

Paul IA, Skolnick P (2003). Glutamate and depression: clinical and preclinical studies. Ann NY Acad Sci 1003: 250-272.

Pittenger C, Sanacora G, Krystal JH (2007). The NMDA receptor as a therapeutic target in major depressive disorder. CNS Neurol Disord Drug Targets 6: 101-115.

Prickaerts J, Moechars D, Cryns K, Lenaerts I, van Craenendonck $\mathrm{H}$, Goris I et al (2006). Transgenic mice overexpressing glycogen synthase kinase 3 beta: a putative model of hyperactivity and mania. J Neurosci 26: 9022-9029.

Quiroz JA, Singh J, Gould TD, Denicoff KD, Zarate CA, Manji HK (2004). Emerging experimental therapeutics for bipolar disorder: clues from the molecular pathophysiology. Mol Psychiatry 9: 756-776.

Roth BL, Sheffler DJ, Kroeze WK (2004). Magic shoguns versus magic bullets: selectively non-selective drugs for mood disorders and schizophrenia. Nat Rev Drug Discov 3: 353-359.

Rothstein JD, Patel S, Regan MR, Haenggeli C, Huang YH, Bergles $\mathrm{DE}$ et al (2005). Beta-lactam antibiotics offer neuroprotection by increasing glutamate expression. Nature 433: 73-77.

Roybal K, Theobold D, Graham A, DiNieri JA, Russo SJ, Krishnan $\mathrm{V}$ et al (2007). Mania-like behavior induced by disruption of CLOCK. Proc Natl Acad Sci USA 104: 6406-6411.

Ruhe HG, Mason NS, Schene AH (2007). Mood is indirectly related to serotonin, norepinephrine and dopamine levels in humans: a meta-analysis of monoamine depletion studies. Mol Psychiatry 12: $331-359$.

Salomé N, Stemmelin J, Cohen C, Griebel G (2006). Selective blockade of NK2 or NK3 receptors produces anxiolytic- and antidepressant-like effects in gerbils. Pharmacol Biochem Behav 83: 533-539.

Sanacora G, Kendell SF, Levin Y, Simen AA, Fenton LR, Coric V et al (2007). Preliminary evidence of riluzole efficacy in antidepressant-treated patients with residual depressive symptoms. Biol Psychiatry 61: 822-825.

Sanacora G, Rothman DL, Mason G, Krystal JH (2003). Clinical studies implementing glutamate neurotransmission in mood disorders. Ann NY Acad Sci 1003: 292-308.

Sanacora G, Saricicek A (2007). GABAergic contributions to the pathophysiology of depression and the mechanism of antidepressant action. CNS Neurol Disord Drug Targets 6: 127-140.

Sattler R, Rothstein JD (2007). Targeting an old mechanism in a new disease-protection of glutamatergic dysfunction in depression. Biol Psychiatry 61: 137-138.

Schloesser RJ, Huang J, Klein PS, Manji HK (2008). Cellular plasticity cascades in the pathophysiology and treatment of bipolar disorder. Neuropsychopharmacology 33: 110-133.

Shen J (2006). 13C magnetic resonance spectroscopy studies of alterations in glutamate neurotransmission. Biol Psychiatry 59: 883-887.

Shortland PJ, Leinster VH, White W, Robson LG (2006). Riluzole promotes cell survival and neurite outgrowth in rat sensory neurones in vitro. Eur J Neurosci 24: 3343-3353.

Siuciak JA, Chapin DS, McCarthy SA, Martin AN (2007). Antipsychotic profile of rolipram: efficacy in rats and reduced sensitivity in mice deficient in the phosphodiesterase-4B (PDE4B). Psychopharmacology (Berl) 192: 415-424.
Spedding M, Jay T, Costa e Silva J, Perret L (2005). A pathophysiological paradigm for the therapy of psychiatric disease. Nat Rev Drug Discov 4: 467-476.

Trivedi MH, Rush AJ, Wisniewski SR, Nierenberg AA, Warden D, Ritz L et al (2006). Evaluation of outcomes with citalopram for depression using measurement-based care in $\mathrm{STAR}^{\star} \mathrm{D}$ : implications for clinical practice. Am J Psychiatry 163: 28-40.

Valdez GR (2006). Development of CRF1 receptor antagonists as antidepressants and anxiolytics; progress to date. CNS Drugs 20: 887-896.

van der Hart MG, de Biurrun G, Czéh B, Rupniak NM, den Boer JA, Fuchs E (2005). Chronic psychosocial stress in tree shrews: effect of the substance $\mathrm{P}$ (NK1 receptor) antagonist L-760735 and clomipramine on endocrine and behavioral parameters. Psychopharmacology (Berl) 181: 207-216.

Wachtel H, Schneider HH (1986). Rolipram, a novel antidepressant drug, reverses the hypothermia and hypokinesia of monoaminedepleted mice by an action beyond postsynaptic monoamine receptors. Neuropharmacology 25: 1119-1126.

Wedzony K, Klimek V, Nowak G (1995). Rapid down-regulation of beta-adrenergic receptors evoked by combined forced swimming test and CGP 37849-a competitive antagonist of NMDA receptors. Pol J Pharmacol 47: 537-540.

Wong ML, Licinio J (2004). From monoamines to genomic targets: a paradigm shift for drug discovery in depression. Nat Rev Drug Discov 3: 1-16.

Zarate Jr CA, Charney DS, Manji HK (2007a). Searching for rational anti- $N$-methyl-D-asparte treatment for depression [in reply]. Arch Gen Psychiatry 64: 1100-1101.

Zarate Jr CA, Du J, Quiroz J, Gray NA, Denicoff KD, Singh J et al (2003). Regulation of cellular plasticity cascades in the pathophysiology and treatment of mood disorders: role of the glutamatergic system. Ann NY Acad Sci 1003: 273-291.

Zarate CA, Payne JL, Quiroz J, Sporn J, Denicoff KK, Luckenbaugh D et al (2004a). An open label trial of riluzole in patients with treatment resistant major depression. Am J Psychiatry 161: 171-174.

Zarate Jr CA, Payne JL, Singh J, Quiroz JA, Luckenbaugh DA, Denicoff KD et al (2004b). Pramipexole for bipolar II depression: a placebo-controlled proof of concept study. Biol Psychiatry 56: 54-60.

Zarate CA, Quiroz JA, Singh JB, Denicoff KD, De Jesus G, Luckenbaugh DA et al (2005). An open-label trial of the glutamate-modulating agent riluzole in combination with lithium for the treatment of bipolar depression. Biol Psychiatry 57: $430-432$.

Zarate CA, Singh JB, Carlson PJ, Brutsche NE, Ameli R, Luckenbaugh DA et al (2006a). A randomized trial of an NMDA antagonist in treatment-resistant major depression. Arch Gen Psychiatry 63: 856-864.

Zarate Jr CA, Singh JB, Carlson PJ, Quiroz J, Jolkovsky L, Luckenbaugh D et al (2007b). Efficacy of a protein kinase C inhibitor (tamoxifen) in the treatment of acute mania: a pilot study. Bipolar Disord 9: 561-570.

Zarate CA, Singh JB, Manji HK (2006b). Cellular plasticity cascades: targets for the development of novel therapeutics for bipolar disorder. Biol Psychiatry 59: 1006-1020.

Zarate CA, Singh JB, Quiroz JA, DeJesus G, Denicoff K, Luckenbaugh DA et al (2006c). A double-blind placebocontrolled study of memantine in major depression. Am J Psychiatry 163: 153-155.

Zhao Y, Altman BJ, Coloff JL, Herman CE, Jacobs SR, Wieman HL et al (2007). Glycogen synthase kinase 3alpha and 3beta mediate a glucose-sensitive antiapoptotic signaling pathway to stabilize Mcl-1. Mol Cell Biol 27: 4328-4339.

Zobel A, Nickel T, Künzel H, Ackl N, Sonntag A, Ising M et al (2000). Effects of the high-affinity corticotropin-releasing hormone receptor 1 antagonist R121919 in major depression: the first 20 patients treated. J Psychiatr Res 34: 171-181. 